УДК 616.12-008.331.1+616.379-008.9]-092:577.125.8

https://doi.org/10.30702/card:sp.2019.08.037/0295668

Чернишов В. А. ${ }^{1}$, Несен А. О. ${ }^{1}$, Валентинова І. А. ${ }^{1}$, Єрмакович I. I. ${ }^{2}$

${ }^{1}$ ДУ «Національній інститут терапії імені Л. Т. Малої НАМН України», м. Харків, Україна

2ТОВ «Медичний центр здоров'я», м. Харків, Україна

Chernyshov V. ${ }^{1}$, Nesen A. ${ }^{1}$, Valentinova I. ${ }^{1}$, Yermakovych I. ${ }^{2}$

${ }^{1}$ L.T. Malaya Therapy National Institute of the National Academy of Medical Sciences of Ukraine, Kharkiv, Ukraine

${ }^{2}$ Medical health centre, Kharkiv, Ukraine

\title{
The Relations between Lipid and Purine Metabolism Disorders in Patients with Essential Hypertension and Insulin Resistance
}




\section{$\square$ Abstract}

The work aimed to investigate the relations between hyperuricaemia (HUE) and state of lipid metabolism in patients (pts) with essential hypertension (EH) and insulin resistance (IR).

Materials and methods. In retrospective investigation based on history case data, the results of 123 pts examination (54 females and 69 males) aged 20 to 77 years old (average age (55.13 \pm 1.38$)$ ) were included. Except EH of I-III stages, 59 (48.0\%) of pts had IR and 40 (32.5\%) of pts were with HUE. Some serum blood parameters at fasting state before treatment prescription such as body mass index, HOMA-IR index (homeostasis model assessment of insulin resistance), glucose, insulin, uric acid (UA), total cholesterol (TC), high-density lipoprotein cholesterol (HDL-C) were taken from the history cases. Some additional parameters were calculated by known formulas including fat body percentage, fat mass index (FMI), non-HDL-C, very low-density lipoprotein cholesterol (VLDL-C), low-density lipoprotein cholesterol (LDL-C), triglyceride and glucose index (TGGI) as well as lipid ratios (LDL-C/HDL-C, non-HDL-C/TC, TC/HDL-C, TG/HDL-C and atherogenic serum blood index (ASBI) as a $\log (T G / H D L-C))$.

$\square$ Results and discussion. In pts with $\mathrm{EH}$ and IR compared with ones without IR there was an elevation of such lipid ratios as TC/HDL-C and TG/HDL-C by $20.7 \%$ and $92.2 \%(p<0.01)$ correspondingly as well as reverse correlation between HOMA-IR index and HDL-C level $(r=$ 
$-0.394 ; p<0.003)$ and elevation in 2.87 times of ASBI $(p<0.01)$. The pts with $\mathrm{EH}, \mathrm{IR}$ and HUE compared with insulin-resistant pts without HUE had a decrease in HDL-C by $23.6 \%(p<0.001)$, an elevation of serum TG and VLDL-C by $31.0 \%(p<0.05)$ as well as a decrease in LDL-C by $28.2 \%(p<0.05)$ due to elevation of TG. In pts with EH and $I R$, there was a correlation between UA and lipid markers of IR $(r=$ $0.411 ; p<0.004$ for HOMA-IR index and $r=0.389 ; p<0.002$ for TGGI) confrmed a contribution of IR to serum UA concentration. The association between UA level and lipid ratio TG/HDL-C $(r=0.379 ; p<$ $0.001)$ as well as ASBI $(r=0.363 ; p<0.003)$ was revealed in insulin-resistant pts. In pts with $\mathrm{EH}, \mathrm{IR}$ and HUE visceral fat accumulation contributed to TG elevation ( $r=0.317$; $p<0.004$ for FMI and TG) and to HDL-C level decrease ( $r=-0.305 ; p<0.05$ for FMI and $\mathrm{HDL}-\mathrm{C})$ and hyperinsulinaemia associated with HDL-C level decrease ( $r$ $=-0.308 ; p<0.002)$.

Conclusions. The pts with EH and IR have some impairments in lipid metabolism, in particular, an intensification of atherogenic shifts in the system of reverse cholesterol transport and in the system of lipoprotein TG-VLDL lipolysis as well as a presence of small dense LDL in circulation. HUE intensifies a decrease in HDL-C and an elevation of $T G$ in pts with $E H$ and IR and the latter contributes to UA elevation in blood serum. HUE in pts with EH associates with small dense LDL presence in circulation. Visceral fat accumulation in pts with $E H, I R$, and HUE contributes to TG elevation and together with hyperinsulinaemia promotes a decrease in HDL-C.

Keywords: dyslipidaemia, hyperuricaemia, insulin resistance, relations. 
Резюме. Мета роботи - уточнити взаємозв'язок гіперурикемії (ГУЕ) зі станом ліпідного обміну у хворих з гіпертонічною хворобою (ГХ) з інсулінорезистентністю (IP).

\ Матеріали та методи. У ретроспективне дослідження за даними історій хвороб увійшли результати обстеження 123 пацієнтів - 54 (43,9 \%) жінки і 69 (56,1\%) чоловіків віком від 20 до 77 років (середній вік 55,13 \pm 1,38 року) з гіпертонічною хворобою I-III стадії, які перебували на обстеженні й лікуванні в клініці ДУ «Національний інститут терапії імені Л. Т. Малої НАМН України» і в яких у 59 (48 \%) випадках виявлено IP та в 40 (32,5\%) - ГУЕ.

З історій хвороб вилучено дані про індекс маси тіла, індекс HOMA-IR (homeostasis model assessment of insulin resistance), рівні глюкози, інсуліну, сечової кислоти (CK), загального холестерину (ЗХC), тригліцеридів (ТГ), холестерину (XC) ліпопротеїдів високої щільності (ЛПВЩ) до призначення пацієнтам медикаментозної терапії. Додатково за відомими формулами розраховували такі показники: відсоток жирових відкладень, індекс маси жиру (IMЖ), XC неЛПВЩ, XС ліпопротеїдів дуже низької щільності (ЛПДНЩ), ХС ліпопротеїдів низької щільності (ЛПНЩ), тригліцерид-глюкозний індекс (ТГГІ), ліпідні співвідношення (XC 
ЛПНЩ / XС ЛПВЩ, XС не-ЛПВЩ / ЗХС, ЗХС / XС ЛПВЩ, ТГ / XС ЛПВЩ та log (ТГ / ХС ЛПВЩ) - атерогенний індекс сироватки крові $(\mathrm{AICK}))$.

Результати та обговорення. У хворих з гіпертонічною хворобою та IP, на відміну від пацієнтів без IP, спостерігається підвищення ліпідних співвідношень ЗХС / ХС ЛПВЩ і ТГ / ХС ЛПВЩ відповідно на 20,7 \% і 92,2\% ( $<<0,01)$, зворотна залежність рівня ХС ЛПВЩ від величини індексу HOMA-IR $(r=-0,394 ; p<0,003)$ та перебільшення в 2,87 раза величини AICK $(p<0,01)$. У хворих з ГX з IP та ГУЕ, на відміну від пацієнтів з IP, яка перебігає без підвищення СК, виявлено зниження XС ЛПВЩ на 23,6 \% ( $<<$ 0,001), підвищення вмісту в сироватці крові ТГ і ХС ЛПДНЩ на 31 $\%(p<0,05)$, зниження рівня XС ЛПНЩ на $28,2 \%(p<0,05)$ за рахунок підвищення концентрації ТГ.

Висновки. У хворих з ГX і IP спостерігається погіршення стану ліпідного обміну, зокрема посилення атерогенних зрушень у системах зворотного транспорту XC і ліпопротеїдліполізу ТГ-вмісних ЛПДНЩ, наявність у кровоплині дрібних щільних частинок ЛПНЩ. Гіперурикемія посилює зниження ХС ЛПВЩ, підвищення ТГ у пацієнтів з ГХ і IP, а остання призводить до підвищення рівня СК. Гіперурикемія у хворих з гіпертонічною хворобою асоціюється з наявністю в кровоплині дрібних щільних частинок ЛПНЩ. Вісцеральні жирові накопичення в пацієнтів з ГХ, IP та ГУЕ зумовлюють підвищення рівня ТГ і зниження ХC ЛПВЩ, а гіперінсулінемія асоціюється зі зниженням умісту ХС у складі ЛПВЩ. 
૧Ключові слова: дисліпідемія, гіперурикемія, інсулінорезистентність, взаємозв'язок. 